\title{
The Federal Democratic Republic of Ethiopia: Debt Sustainability Analysis
}

This Debt Sustainability Analysis paper for The Federal Democratic Republic of Ethiopia was prepared by a staff team of the International Monetary Fund as background documentation for the periodic consultation with the member country. It is based on the information available at the time it was completed on August 25, 2004. The views expressed in this document are those of the staff team and do not necessarily reflect the views of the government of The Federal Democratic Republic of Ethiopia or the Executive Board of the IMF.

The policy of publication of staff reports and other documents by the IMF allows for the deletion of market-sensitive information.

To assist the IMF in evaluating the publication policy, reader comments are invited and may be sent by e-mail to publicationpolicy@imf.org.

Copies of this report are available to the public from

International Monetary Fund $\bullet$ Publication Services

700 19th Street, N.W. • Washington, D.C. 20431

Telephone: (202) 6237430 • Telefax: (202) 6237201

E-mail: publications@imf.org • Internet: http://www.imf.org

Price: $\$ 15.00$ a copy

\section{International Monetary Fund Washington, D.C.}





\section{INTERNATIONAL MONETARY FUND \\ THE FEDERAL DEMOCRATIC REPUBLIC OF ETHIOPIA}

\section{Debt Sustainability Analysis}

Prepared by a staff team from the African, Fiscal Affairs and Policy Development and Review Departments

Approved by Siddharth Tiwari and G. Russell Kincaid

August 25, 2004

\section{External Debt Sustainability Assessment}

1. This brief supplement presents a debt sustainability analysis (DSA) using the new framework for low-income countries considered by the Boards of Fund and Bank earlier this year. ${ }^{1}$ The macroeconomic scenario underlying this DSA is the baseline scenario discussed in the Article IV Staff Report and described in Section III.A of the report. ${ }^{2}$ The framework takes into account economic developments since the HIPC Completion Point and new information received in the context of the 2004 Article IV consultation discussions, including information received from donors. The salient features of the revised macroframework are lower loan disbursements fully offset by higher grants. Exports of goods and nonfactor services are also higher in the initial years of the projection period, reflecting a strong pickup in exports in 2003/04.

2. Application of the new methodology for assessing external debt sustainability in lowincome countries yields the following results:

- Under the baseline scenario, the ratios of NPV of debt-to-GDP and exports are projected to rise somewhat in the initial years reaching 25 percent and 170 percent respectively in 2008/09 (182 percent of exports using a three-year backward looking average); and are then projected to gradually decline. External debt service absorbs on average about 6 percent of export revenues over the next 15 years, rising to a

\footnotetext{
${ }^{1}$ Debt Sustainability in Low-Income Countries-Proposal for an Operational Framework and Policy Implications.

${ }^{2}$ The Federal Democratic Republic of Ethiopia-Staff Report for the 2004 Article IV Consultation and Sixth Review Under the Three-Year Arrangement Under the Poverty Reduction and Growth Facility.
} 
moderate 8 percent during the last years of the projection period as concessional debt comes to maturity and debt service reduction under the HIPC Initiative is exhausted. ${ }^{3}$ These results are robust with respect to the choice of the denominator for the NPV of debt-to-exports ratio based on either current year exports (Table 2a) or a three-year average of exports (presented in Appendix I).

- The stress tests however reveal that Ethiopia's external debt and debt service indicators are particularly sensitive to the terms of new borrowing and negative export shocks. Although the NPV of debt-to-exports ratio deteriorates under most stress tests, it is under new borrowing on less favorable terms and under the simulated export shock that the adverse impact is most significant. Under the less favorable financing scenario, the NPV of debt-to-exports ratio increases rapidly by as much as 60-70 percentage points compared to the baseline, while a shock to export growth results in an NPV of debt-to-exports ratio that stays above 200 percent for about 15 years.

- $\quad$ The baseline projections appear fragile to adverse shocks and embody optimistic assumptions relative to Ethiopia's historical trend over the past 10 years. Under both the historic and the most extreme stress scenarios, the ratios of NPV of debt-to-GDP and exports stay above the appropriate upper benchmarks for most of the projection period even though the debt-service ratio remains well within the manageable range. This underscores the importance for the government of Ethiopia to follow a prudent borrowing strategy with new borrowing on highly concessional terms and with an increased reliance on grant financing, as well on a comprehensive debt management strategy to safeguard against a reemergence of an external debt burden.

- $\quad$ The quality of a country's policies and institutions are important for assessing debt sustainability. According to one such measure of policies and institutions, the World Bank's Country Policy and Institutional Assessment (CPIA) index, Ethiopia is in the third quintile and its policies and institutions are thus considered to be of moderate strength. As an illustration, the policy-dependent indicative upper benchmarks for debt sustainability for such a country are: an NPV of debt-to-GDP ratio of 45 percent and NPV of debt-to-exports ratio of 200 percent, with a corresponding debt service-to-exports ratio of 25 percent. Ethiopia's external debt burden indicators remain at or below the relevant World Bank's CPIA-linked

\footnotetext{
${ }^{3}$ Such a situation where an increasing NPV of debt-to-exports ratio in the initial years is accompanied by a low debt service ratio is not uncommon among countries graduating from the HIPC Initiative that have benefited from a rescheduling of their existing obligations and have begun (or are projected) to borrow new funds after their completion points.
} 
indicative policy-based thresholds, with a particularly wide margin for the debtservice ratio. ${ }^{4}$

\section{Decomposition of the Impact of Methodological Changes and Revisions to the Macroframework}

3. The estimates of NPV of debt-to-exports ratio obtained under the new methodology are considerably lower than those estimated at the time of the HIPC completion point. The differences are due to methodological differences as well as to changes in economic variables. These changes and the contribution of various factors are considered in this section.

4. The impact of the new DSA methodology was estimated as the difference between the completion point estimate and the estimate obtained when the new methodology is applied to the data set used at completion point. Changes in the macroeconomic framework underlying the Article IV Staff Report relative to the completion point projections account for the remainder. This approach is illustrated in Figure 1 and the decomposition results for 2003/04 are presented in Table 1. As shown in Table 1, methodological changes account for about half of the total reduction in the ratio of NPV of debt-to-exports, of which about 13 percentage points correspond to changes affecting the numerator of the ratio (mainly the use of new parameters to calculate the NPV of debt), and 10 percentage points correspond to changes affecting the denominator (shift from three-year average to current year exports). The revisions to the macroeconomic framework since the completion point account for a reduction of 29 percentage points. Lower loan disbursements than projected at the completion point account for a reduction of about 7 percentage points, while higher than expected exports of goods and non-factor services account for the remainder.

\section{Public Debt Sustainability Assessment}

5. The DSA for the public debt reflects the baseline macro and fiscal framework as described in Sections III.A and III.B of the main report. ${ }^{5}$ The framework incorporates a declining trend in the primary fiscal deficit, higher-than-average growth in real GDP, and modest real interest rates for new domestic borrowing. The results of the DSA entail a decline in the ratio of public debt to GDP and revenue, while the debt service-to-revenue ratio is projected to decline comfortably. For instance, the NPV of the public debt to GDP is set to decline from 55 percent to about 35 percent over the projection horizon. Despite these encouraging trends, there remain risks for achieving a sustainable profile in the public debt, particularly if growth remains at the historical average or real interest rates increase for domestic borrowing. The public debt position remains vulnerable to frequent exogenous

\footnotetext{
${ }^{4}$ The Executive Board has not yet decided on such thresholds for operational purposes.

${ }^{5}$ The coverage of public debt includes both public and publicly guaranteed obligations to domestic and external creditors.
} 
shocks in agriculture and to accelerated structural reforms of the financial sector that could raise debt-service commitments for the domestic debt. The stock of domestic debt in Ethiopia is also currently high at about 34 percent of $\operatorname{GDP}^{6}$ (Table 3a). ${ }^{7}$

6. The results of applying the new DSA framework for public debt are summarized below:

- $\quad$ The public debt DSA indicates some risk arising from output growth and the primary balance remaining at historical averages (Table $3 \mathrm{~b}, \mathrm{~A} 1$ ). However, the historical average for the primary fiscal balance largely reflects extraordinary factors related to the conflict with Eritrea.

- $\quad$ The key public debt indicators initially rise during 2004/05 under the baseline scenario, in tandem with the external component of the public debt. In contrast, the domestic debt is projected to decline steadily to contain inflationary pressure and provide sufficient credit to facilitate private sector development.

- $\quad$ The stress tests in the alternative scenarios suggest that lower GDP growth represents the principal sensitivity factor. For instance, the results indicate that permanently lower GDP growth relative to the baseline scenario (Table 3b, A3) could modestly increase the NPV of debt-to-GDP and revenue ratios over the 20-year horizon. The return of primary fiscal deficits to the high levels of the late 1990s (about 8-9 percent of GDP) would also contribute negatively to public debt sustainability, particularly in conjunction with GDP growth remaining at the historical average (Table 3b, A1). In this combined scenario, the NPV of the public debt to GDP and revenue would increase sharply by 25 percent and 74 percent, respectively. However, under forward looking scenarios, the public debt indicators follow downward profiles.

\footnotetext{
${ }^{6}$ This compares to the NPV of external debt to GDP at about 21 percent.

${ }^{7}$ Domestic debt differs from external debt in terms of coverage, lending terms, economic impact, rollover risk and other factors.
} 
Table 1. Ethiopia: Breakdown of the Difference in the NPV of debt-to-exports ratio at end-FY 2003/04 between HIPC Completion Point estimates and 2004 Article IV estimates (In percentage points, unless otherwise indicated)

\begin{tabular}{|c|c|c|c|}
\hline $\begin{array}{l}\text { Factors explaining the change in the NPV of debt-to-exports } \\
\text { ratio }\end{array}$ & $\begin{array}{r}\text { Impact of methodological } \\
\text { changes }\end{array}$ & $\begin{array}{l}\text { Impact of changes of } \\
\text { economic variables }\end{array}$ & Total \\
\hline (i) Parameters used to calculate the NPV of debt $1 /$ & -15.3 & 0.0 & -15.3 \\
\hline (ii) New borrowing & 1.9 & -7.2 & -5.3 \\
\hline (iiia) Exports of goods and non-factor services (three year average) & 0.0 & -9.4 & -9.4 \\
\hline (iiib) Exports of goods and non-factor services (current year) 2/ & -10.0 & -21.8 & -31.7 \\
\hline \multicolumn{4}{|l|}{ Memorandum items: } \\
\hline & $\begin{array}{r}\text { HIPC Completion Point } \\
\text { with topping-up } \\
\end{array}$ & $\begin{array}{r}2004 \text { Article IV baseline } \\
\text { with topping-up } \\
\end{array}$ & Total 3/ \\
\hline (a) End-FY 2003/04 NPV of debt-to-exports ratio (in percent) & 178.6 & 148.5 & -30.1 \\
\hline (b) End-FY 2003/04 NPV of debt-to-exports ratio (in percent) 2/ & $\ldots$ & 126.2 & -52.4 \\
\hline \multicolumn{4}{|l|}{ Exports of goods and non-factor services (millions of U.S. dollars) } \\
\hline Current & $1,168.0$ & $1,369.4$ & \\
\hline Three year average & $1,096.8$ & $1,163.9$ & \\
\hline
\end{tabular}

$1 /$ Corresponds to the impact of using the WEO exchange rate projections and a 5 percent discount rate (as per the Low Income Country DSA methodology) instead of end-June 2003 exchange rates and currency-specific CIRRs (as per the HIPC methodology).

(Subsumes the impact of exchange rate changes since end-FY 2002/03.)

2/ Corresponds to the impact of using current year exports instead of three-year backward looking average.

3/ The difference between the 2004 Article IV baseline and the HIPC Completion Point baseline. Equals the sum of lines (i), (ii) and (iiia) and (iiib), respectively. 
Figure 1. Ethiopia: NPV of debt-to-exports ratio (In percent)

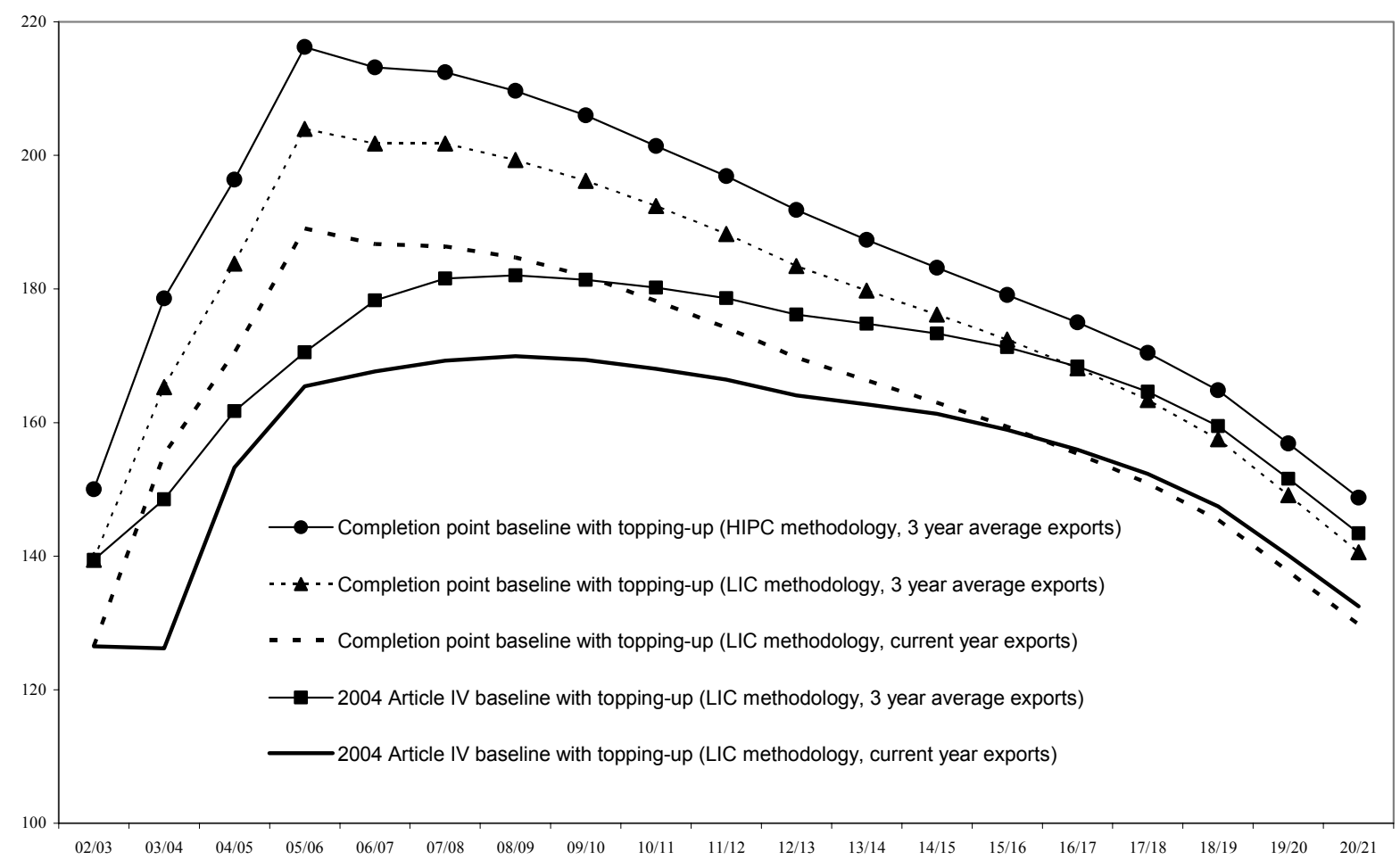




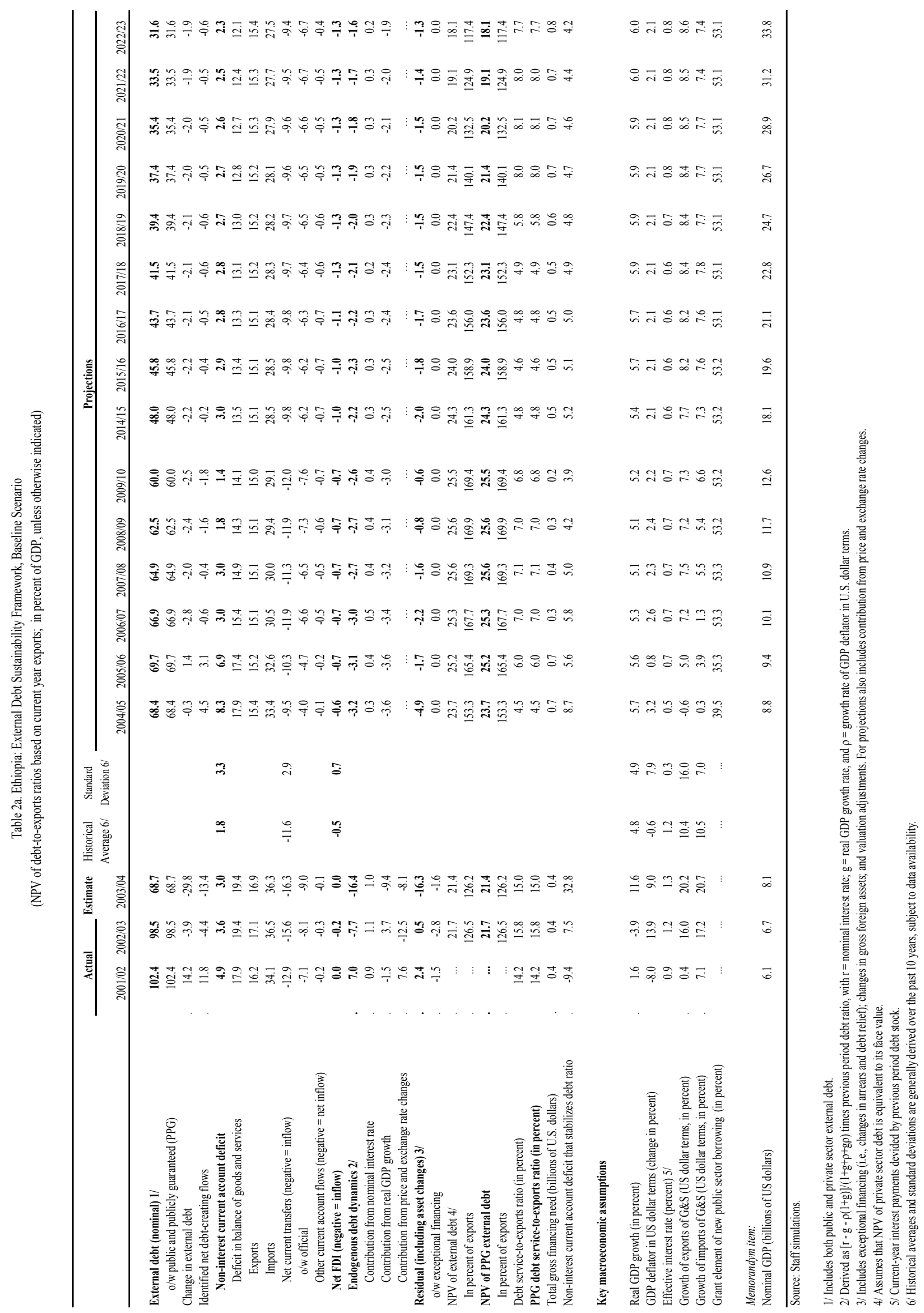


Table 2b. Ethiopia: Sensitivity Analyses for Key Indicators of Public and Publicly Guaranteed External Debt (NPV of debt-to-exports ratios based on current year exports; in percent)

Projections

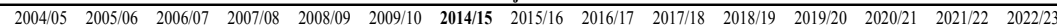

NPV of debt-to-GDP ratio

Baseline

A. Alternative Scenario

A1. Key variables at their historical averages in 2004-231

A2. New public sector loans on less favorable terms in $2004-232$

B. Bound Tests

B1. Real GDP growth at historical average minus one standard deviation in 2004-05 B2. Export value growth at historical average minus one standard deviation in 2004-05 $3 /$ B3. US dollar GDP deflator at historical average minus one standard deviation in 2004-05 B4. Net non-debt creating flows at historical average minus one standard deviation in 2004-05 4 B5. Combination of B1-B4 using one-half standard deviation shocks

B6. One-time 30 percent nominal depreciation relative to the baseline in 20045

$\begin{array}{lllllllllllllll}23.7 & 25.2 & 25.3 & 25.6 & 25.6 & 25.5 & \mathbf{2 4 . 3} & 24.0 & 23.6 & 23.1 & 22.4 & 21.4 & 20.2 & 19.1 & 18.1 \\ & & & & & & & & & & & & & & \\ 23.7 & 23.2 & 23.7 & 24.3 & 25.2 & 26.1 & \mathbf{2 9 . 7} & 30.1 & 30.4 & 30.8 & 31.0 & 30.5 & 29.9 & 29.4 & 28.8 \\ 23.7 & 26.3 & 28.5 & 29.8 & 30.7 & 31.4 & \mathbf{3 2 . 6} & 32.5 & 32.3 & 32.0 & 31.4 & 30.5 & 29.4 & 28.3 & 27.2\end{array}$

$\begin{array}{lllllllllllllll}23.7 & 26.6 & 28.2 & 28.5 & 28.5 & 28.3 & \mathbf{2 7 . 0} & 26.7 & 26.2 & 25.7 & 24.9 & 23.8 & 22.5 & 21.3 & 20.1 \\ 23.7 & 26.0 & 27.7 & 27.9 & 27.8 & 27.6 & \mathbf{2 5 . 9} & 25.5 & 24.9 & 24.3 & 23.5 & 22.4 & 21.2 & 20.0 & 18.8 \\ 23.7 & 27.6 & 31.0 & 31.3 & 31.3 & 31.1 & \mathbf{2 9 . 7} & 29.3 & 28.8 & 28.2 & 27.4 & 26.1 & 24.8 & 23.4 & 22.1 \\ 23.7 & 26.5 & 28.8 & 28.9 & 28.8 & 28.6 & \mathbf{2 6 . 6} & 26.1 & 25.5 & 24.9 & 24.0 & 22.8 & 21.6 & 20.3 & 19.1 \\ 23.7 & 28.1 & 33.9 & 34.1 & 34.0 & 33.7 & \mathbf{3 1 . 5} & 31.0 & 30.3 & 29.5 & 28.5 & 27.1 & 25.7 & 24.2 & 22.8 \\ 23.7 & 35.9 & 36.1 & 36.4 & 36.4 & 36.3 & \mathbf{3 4 . 6} & 34.1 & 33.6 & 32.9 & 31.9 & 30.4 & 28.8 & 27.3 & 25.7\end{array}$

Baseline

A. Alternative Scenario

A1. Key variables at their historical averages in 2004-23 1

A2. New public sector loans on less favorable terms in 2004-23

\section{B. Bound Tests}

B1. Real GDP growth at historical average minus one standard deviation in 2004-05

B2. Export value growth at historical average minus one standard deviation in 2004-05 3 B3. US dollar GDP deflator at historical average minus one standard deviation in 2004-05 B4. Net non-debt creating flows at historical average minus one standard deviation in 2004-05

B5. Combination of B1-B4 using one-half standard deviation shocks

B6. One-time 30 percent nominal depreciation relative to the baseline in 20045

\section{NPV of debt-to-exports ratio}

$\begin{array}{lllllllllllllll}153.3 & 165.4 & 167.7 & 169.3 & 169.9 & 169.4 & \mathbf{1 6 1 . 3} & 158.9 & 156.0 & 152.3 & 147.4 & 140.1 & 132.5 & 124.9 & 117.4\end{array}$

$\begin{array}{lllllllllllllll}153.3 & 152.1 & 156.9 & 160.5 & 167.3 & 173.9 & \mathbf{1 9 7 . 0} & 199.4 & 201.4 & 203.4 & 203.8 & 200.2 & 195.7 & 191.5 & 187.5 \\ 153.3 & 172.8 & 188.6 & 197.4 & 204.1 & 208.7 & \mathbf{2 1 6 . 6} & 215.7 & 214.0 & 211.2 & 2069 & 199.8 & 192.3 & 184.5 & 176.7\end{array}$

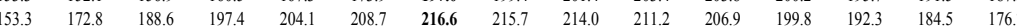

$\begin{array}{lllllllllllllll}153.3 & 165.4 & 167.7 & 169.3 & 169.9 & 169.4 & \mathbf{1 6 1 . 3} & 158.9 & 156.0 & 152.3 & 147.4 & 140.1 & 132.5 & 124.9 & 117.4 \\ 153.3 & 189.7 & 231.4 & 232.8 & 233.1 & 231.8 & \mathbf{2 1 7 . 2} & 213.0 & 208.1 & 202.5 & 195.4 & 185.2 & 174.8 & 164.4 & 154.3 \\ 153.3 & 165.4 & 167.7 & 169.3 & 169.9 & 169.4 & \mathbf{1 6 1 . 3} & 158.9 & 156.0 & 152.3 & 147.4 & 140.1 & 132.5 & 124.9 & 117.4 \\ 153.3 & 174.1 & 190.3 & 191.2 & 191.1 & 190.0 & \mathbf{1 7 6 . 8} & 173.1 & 168.8 & 164.0 & 158.0 & 149.7 & 141.2 & 132.7 & 124.4 \\ 153.3 & 174.2 & 200.9 & 202.0 & 202.0 & 200.9 & \mathbf{1 8 7 . 6} & 183.7 & 179.4 & 174.4 & 168.1 & 159.3 & 150.3 & 141.3 & 132.5 \\ 153.3 & 165.4 & 167.7 & 169.3 & 169.9 & 169.4 & \mathbf{1 6 1 . 3} & 158.9 & 156.0 & 152.3 & 147.4 & 140.1 & 132.5 & 124.9 & 117.4\end{array}$

Debt service ratio

Baseline

A. Alternative Scenarios

A1. Key variables at their historical averages in 2004-23 1

A2. New public sector loans on less favorable terms in $2004-232$

B. Bound Tests

B1. Real GDP growth at historical average minus one standard deviation in 2004-05 B2. Export value growth at historical average minus one standard deviation in 2004-05 3/ B3. US dollar GDP deflator at historical average minus one standard deviation in 2004-05 B4. Net non-debt creating flows at historical average minus one standard deviation in 2004-05 4 B5. Combination of B1-B4 using one-half standard deviation shocks

B6. One-time 30 percent nominal depreciation relative to the baseline in 20045

\begin{tabular}{|c|c|c|c|c|c|c|c|c|c|c|c|c|c|}
\hline \multicolumn{14}{|c|}{ Debt service ratio } \\
\hline 4.5 & 6.0 & 7.0 & 7.1 & 7.0 & 6.8 & 4.8 & 4.6 & 4.8 & 4.9 & 5.8 & 8.0 & 8.1 & 8.0 \\
\hline 4.5 & 6.2 & 7.1 & 7.4 & 7.4 & 7.5 & 5.1 & 5.0 & 5.5 & 6.1 & 7.8 & 11.7 & 12.4 & 12.6 \\
\hline 4.5 & 6.0 & 3.5 & 4.9 & 5.1 & 5.5 & 6.9 & 7.2 & 7.5 & 7.6 & 8.6 & 10.8 & 10.9 & 10.8 \\
\hline
\end{tabular}

Gerandum item:

Grant element assumed on residual financing (i.e., financing required above baseline) $6 /$

$\begin{array}{rrrrrrrrrrrrrrr}4.5 & 6.0 & 7.0 & 7.1 & 7.0 & 6.8 & \mathbf{4 . 8} & 4.6 & 4.8 & 4.9 & 5.8 & 8.0 & 8.1 & 8.0 & 7.7 \\ 4.5 & 6.7 & 9.0 & 9.3 & 9.1 & 8.9 & \mathbf{7 . 1} & 6.7 & 6.9 & 7.0 & 8.0 & 10.7 & 10.8 & 10.6 & 10.2 \\ 4.5 & 6.0 & 7.0 & 7.1 & 7.0 & 6.8 & \mathbf{4 . 8} & 4.6 & 4.8 & 4.9 & 5.8 & 8.0 & 8.1 & 8.0 & 7.7 \\ 4.5 & 6.0 & 7.2 & 7.5 & 7.4 & 7.2 & \mathbf{5 . 9} & 5.6 & 5.7 & 5.8 & 6.6 & 8.7 & 8.8 & 8.6 & 8.3 \\ 4.5 & 6.2 & 7.6 & 8.0 & 7.8 & 7.7 & \mathbf{6 . 2} & 5.9 & 6.0 & 6.1 & 7.0 & 9.2 & 9.3 & 9.1 & 8.8 \\ 4.5 & 6.0 & 7.0 & 7.1 & 7.0 & 6.8 & \mathbf{4 . 8} & 4.6 & 4.8 & 4.9 & 5.8 & 8.0 & 8.1 & 8.0 & 7.7\end{array}$

Source: Staff projections and simulations.

1/ Variables include real GDP growth, growth of GDP deflator (in U.S. dollar terms), non-interest current account in percent of GDP, and non-debt creating flows.

2/ Assumes that the interest rate on new borrowing is by 2 percentage points higher than in the baseline., while grace and maturity periods are the same as in the baseline.

3/Exports values are assumed to remain permanently at the lower level, but the current account as a share of GDP is assumed to return to its baseline level after the shock (implicitly assuming

an offsetting adjustment in import levels).

4/ Includes official and private transfers and FDI

$5 /$ Depreciation is defined as percentage decline in dollar/local currency rate, such that it never exceeds 100 percent.

6/ Applies to all stress scenarios except for A2 (less favorable financing) in which the terms on all new financing are as specified in footnote 2. 
Figure 2. Ethiopia: Indicators of Public and Publicly Guaranteed External Debt Under Alternative Scenarios

(NPV of debt-to-exports ratios based on current year exports, in percent)
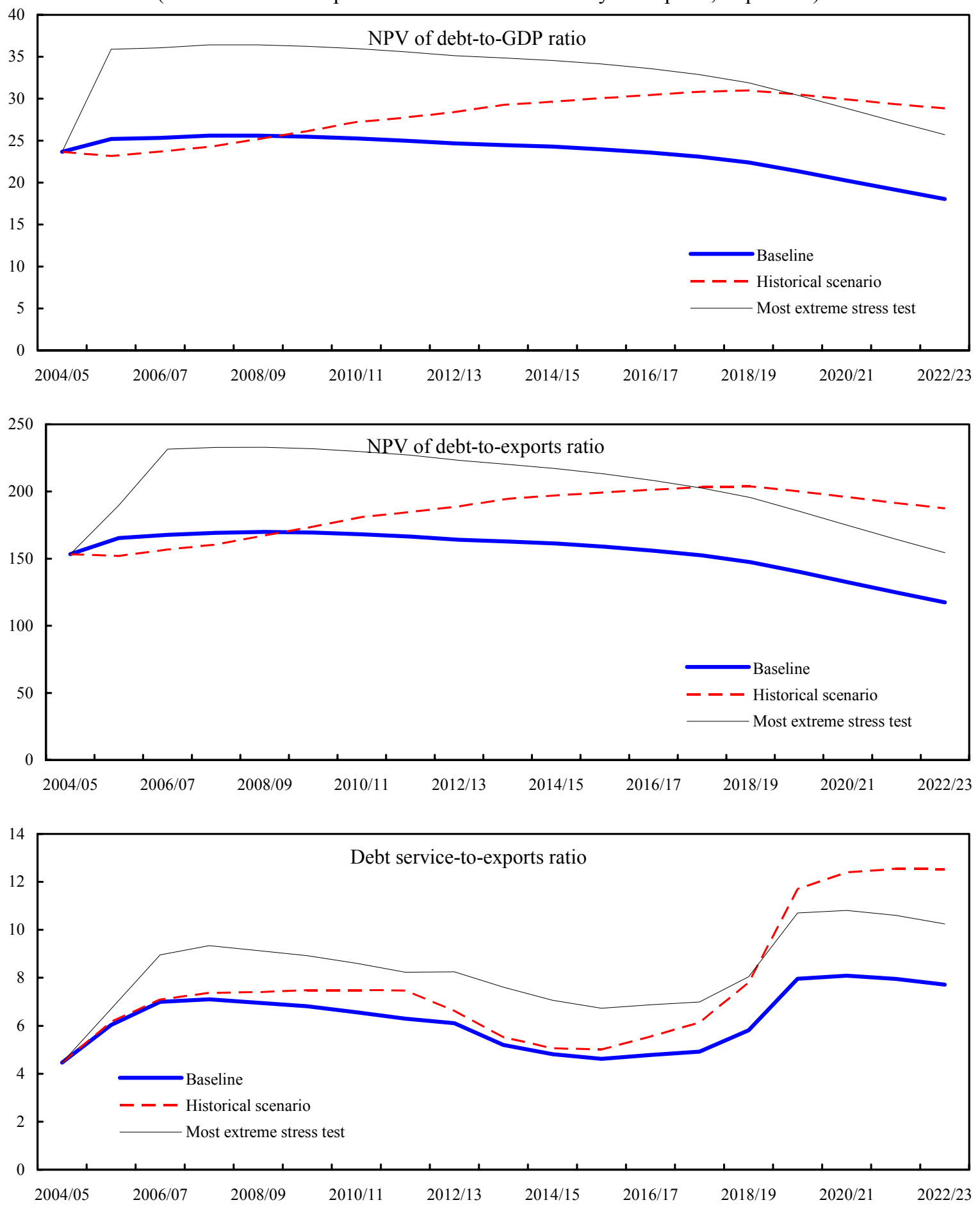

Source: Staff projections and simulations. 
-10 -

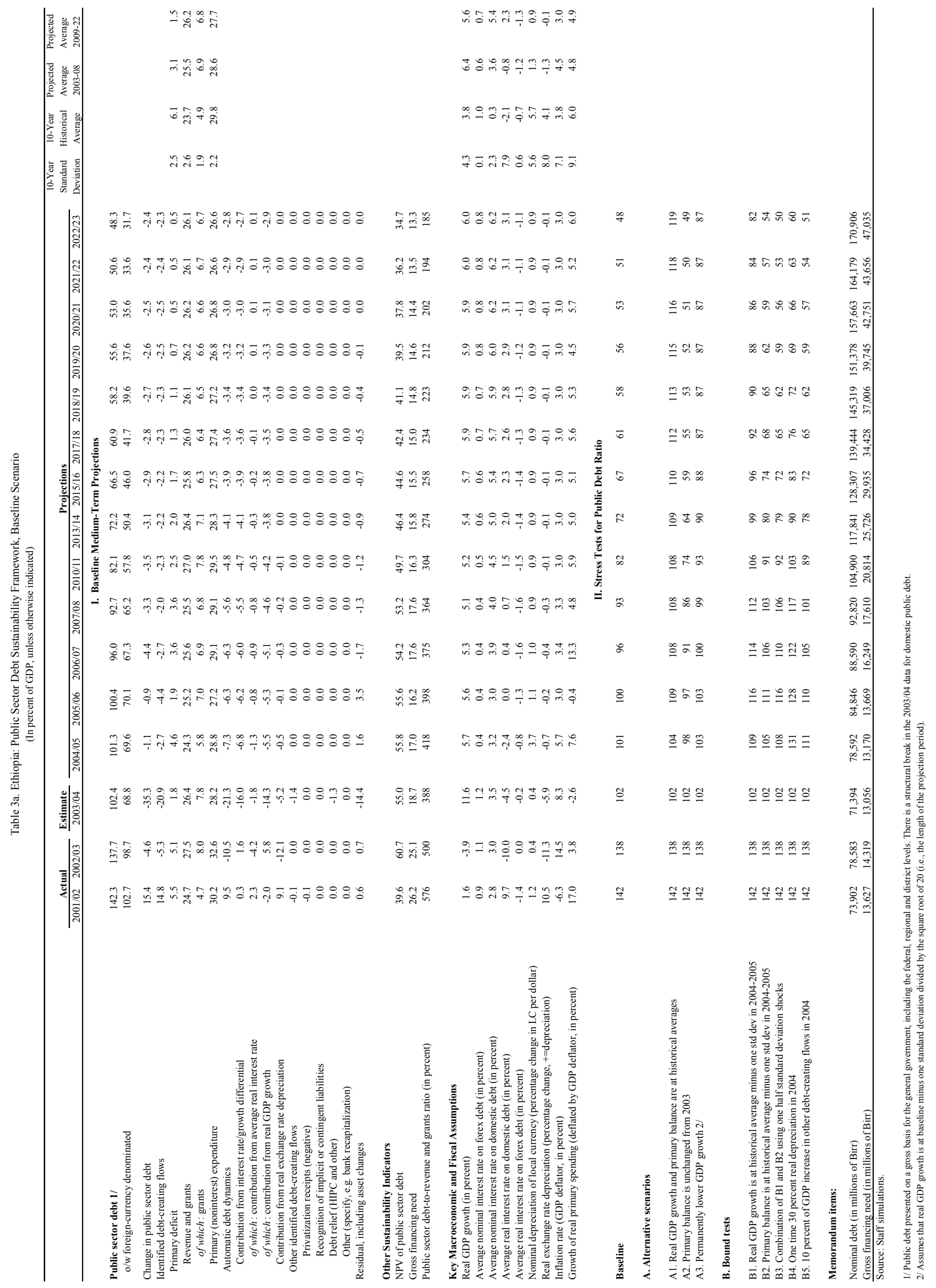


Table 3b. Ethiopia: Sensitivity Analyses for Key Indicators of Public Sector Debt

\begin{tabular}{|c|c|c|c|c|c|c|c|c|}
\hline \multirow[b]{4}{*}{ Baseline } & \multirow{2}{*}{$\begin{array}{r}\text { Estimate } \\
2003 / 04 \\
\end{array}$} & \multicolumn{7}{|c|}{ Projections } \\
\hline & & \multirow[t]{2}{*}{$2004 / 05$} & $2005 / 06$ & $2006 / 07$ & \multicolumn{2}{|c|}{$2007 / 08 \quad 2008 / 09$} & \multirow[t]{2}{*}{$2013 / 14$} & \multirow[t]{2}{*}{$2022 / 23$} \\
\hline & \multicolumn{5}{|c|}{ NPV of Debt-to-GDP Ratio } & & & \\
\hline & 55 & 56 & 56 & 54 & 53 & 52 & 46 & 35 \\
\hline \multicolumn{9}{|l|}{ A. Alternative scenarios } \\
\hline A1. Real GDP growth and primary balance are at historical averages & 55 & $\begin{array}{l}57 \\
54\end{array}$ & $\begin{array}{l}61 \\
54\end{array}$ & 61 & $\begin{array}{l}62 \\
49\end{array}$ & $\begin{array}{l}63 \\
47\end{array}$ & $\begin{array}{l}69 \\
41\end{array}$ & 80 \\
\hline A3. Permanently lower GDP growth $1 /$ & 55 & 56 & 57 & 56 & 56 & 56 & 57 & 59 \\
\hline \multicolumn{9}{|l|}{ B. Bound tests } \\
\hline B1. Real GDP growth is at historical average minus one standard deviation in 2004-2005 & 55 & 60 & 65 & 64 & 64 & 64 & 63 & 56 \\
\hline B2. Primary balance is at historical average minus one standard deviation in 2004-2005 & 55 & 58 & 62 & 60 & 58 & 57 & 51 & 39 \\
\hline B3. Combination of B1 and B2 using one half standard deviation shocks & 55 & 59 & 65 & 62 & 60 & 59 & 51 & 36 \\
\hline B4. One time 30 percent real depreciation in 2004 & 55 & 64 & 62 & 60 & 59 & 58 & 51 & 39 \\
\hline \multirow[t]{2}{*}{ B5. 10 percent of GDP increase in other debt-creating flows in 2004} & 55 & 62 & 61 & 59 & 58 & 56 & 50 & 37 \\
\hline & \multicolumn{8}{|c|}{ NPV of Debt-to-Revenue Ratio 2/ } \\
\hline Baseline & 208 & 230 & 220 & 212 & 209 & 198 & 176 & 133 \\
\hline \multicolumn{9}{|l|}{ A. Alternative scenarios } \\
\hline A1. Real GDP growth and primary balance are at historical averages & 206 & 235 & 238 & 235 & 238 & 233 & 250 & 280 \\
\hline A2. Primary balance is unchanged from 2003 & 206 & 220 & 212 & 199 & 192 & 180 & 157 & 132 \\
\hline A3. Permanently lower GDP growth $1 /$ & 207 & 231 & 224 & 218 & 218 & 211 & 210 & 216 \\
\hline \multicolumn{9}{|l|}{ B. Bound tests } \\
\hline B1. Real GDP growth is at historical average minus one standard deviation in 2004-2005 & 209 & 244 & 249 & 244 & 245 & 236 & 231 & 208 \\
\hline B2. Primary balance is at historical average minus one standard deviation in $2004-2005$ & 207 & 240 & 245 & 233 & 229 & 217 & 194 & 147 \\
\hline B3. Combination of B1 and B2 using one half standard deviation shocks & 207 & 242 & 251 & 237 & 231 & 218 & 188 & 136 \\
\hline B4. One time 30 percent real depreciation in 2004 & 207 & 264 & 247 & 236 & 231 & 218 & 195 & 149 \\
\hline \multirow[t]{2}{*}{ B5. 10 percent of GDP increase in other debt-creating flows in 2004} & 207 & 255 & 240 & 229 & 225 & 214 & 189 & 141 \\
\hline & \multicolumn{8}{|c|}{ Debt Service-to-Revenue Ratio 2/ } \\
\hline Baseline & 12 & 6 & 5 & 6 & 6 & 6 & 6 & 5 \\
\hline \multicolumn{9}{|l|}{ A. Alternative scenarios } \\
\hline A1. Real GDP growth and primary balance are at historical averages & 12 & 6 & 6 & 7 & 7 & 7 & 8 & 10 \\
\hline A2. Primary balance is unchanged from 2003 & 12 & 6 & 5 & 6 & 6 & 5 & 5 & 4 \\
\hline A3. Permanently lower GDP growth $1 /$ & 12 & 6 & 5 & 6 & 6 & 6 & 7 & 8 \\
\hline \multicolumn{9}{|l|}{ B. Bound tests } \\
\hline B1. Real GDP growth is at historical average minus one standard deviation in 2004-2005 & 12 & 6 & 6 & 7 & 7 & 7 & 7 & 8 \\
\hline B2. Primary balance is at historical average minus one standard deviation in 2004-2005 & 12 & 6 & 6 & 7 & 7 & 6 & 7 & 6 \\
\hline B3. Combination of B1 and B2 using one half standard deviation shocks & 12 & 6 & 6 & 7 & 7 & 6 & 7 & 5 \\
\hline B4. One time 30 percent real depreciation in 2004 & 12 & 6 & 6 & 7 & 7 & 6 & 7 & 6 \\
\hline B5. 10 percent of GDP increase in other debt-creating flows in 2004 & 12 & 6 & 6 & 7 & 6 & 6 & 7 & 5 \\
\hline
\end{tabular}

Sources: Country authorities; and Fund staff estimates and projections.

1/ Assumes that real GDP growth is at baseline minus one standard deviation divided by the square root of 20 (i.e., the length of the projection period).

$2 /$ Revenues are defined inclusive of grants. 
Figure 3. Ethiopia: Indicators of Public Debt Under Alternative Scenarios 1/ (In percent)
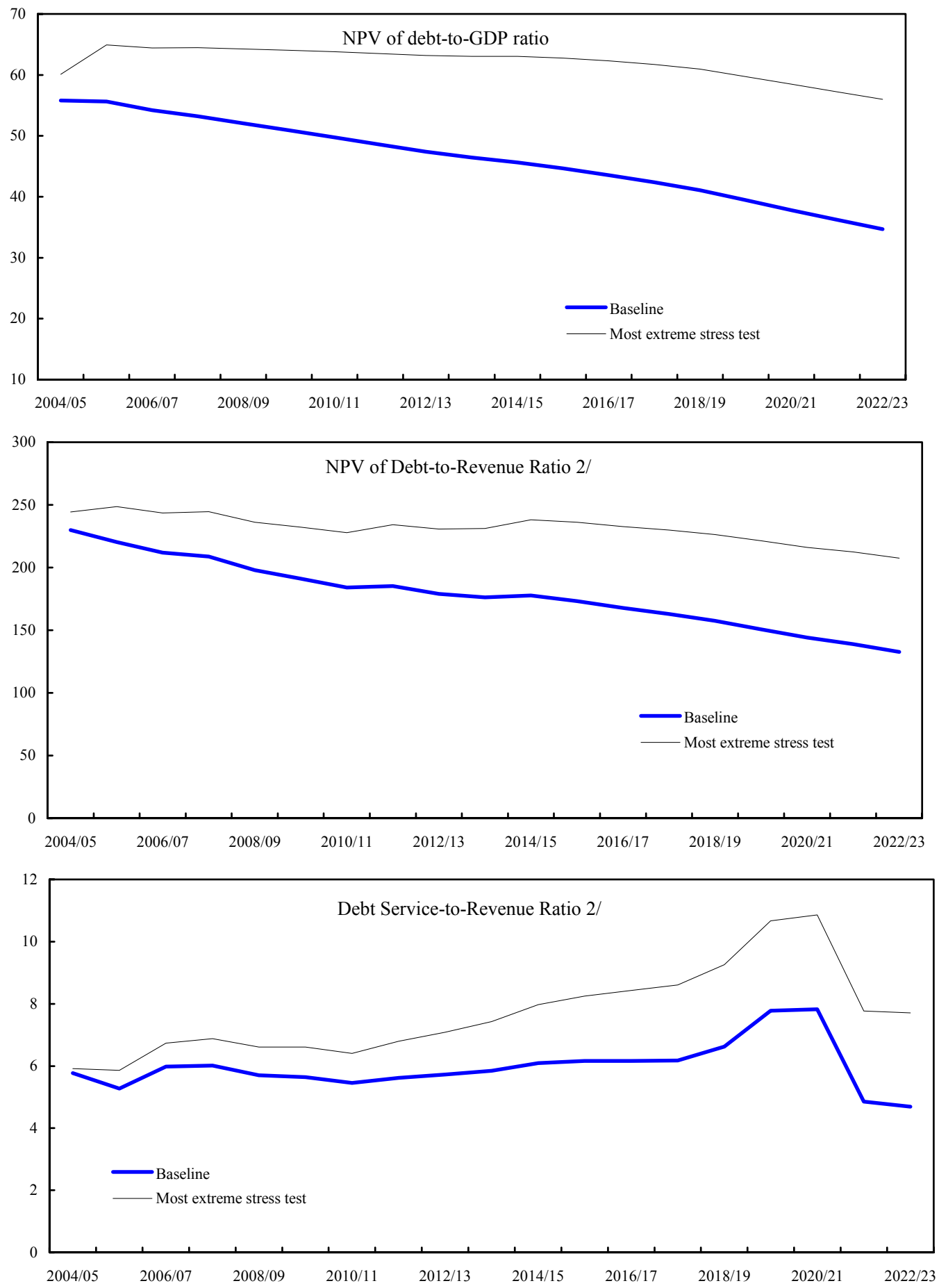

Source: Staff projections and simulations.

1/ Most extreme stress test is test that yields highest ratio in 2013.

2/ Revenue including grants. 


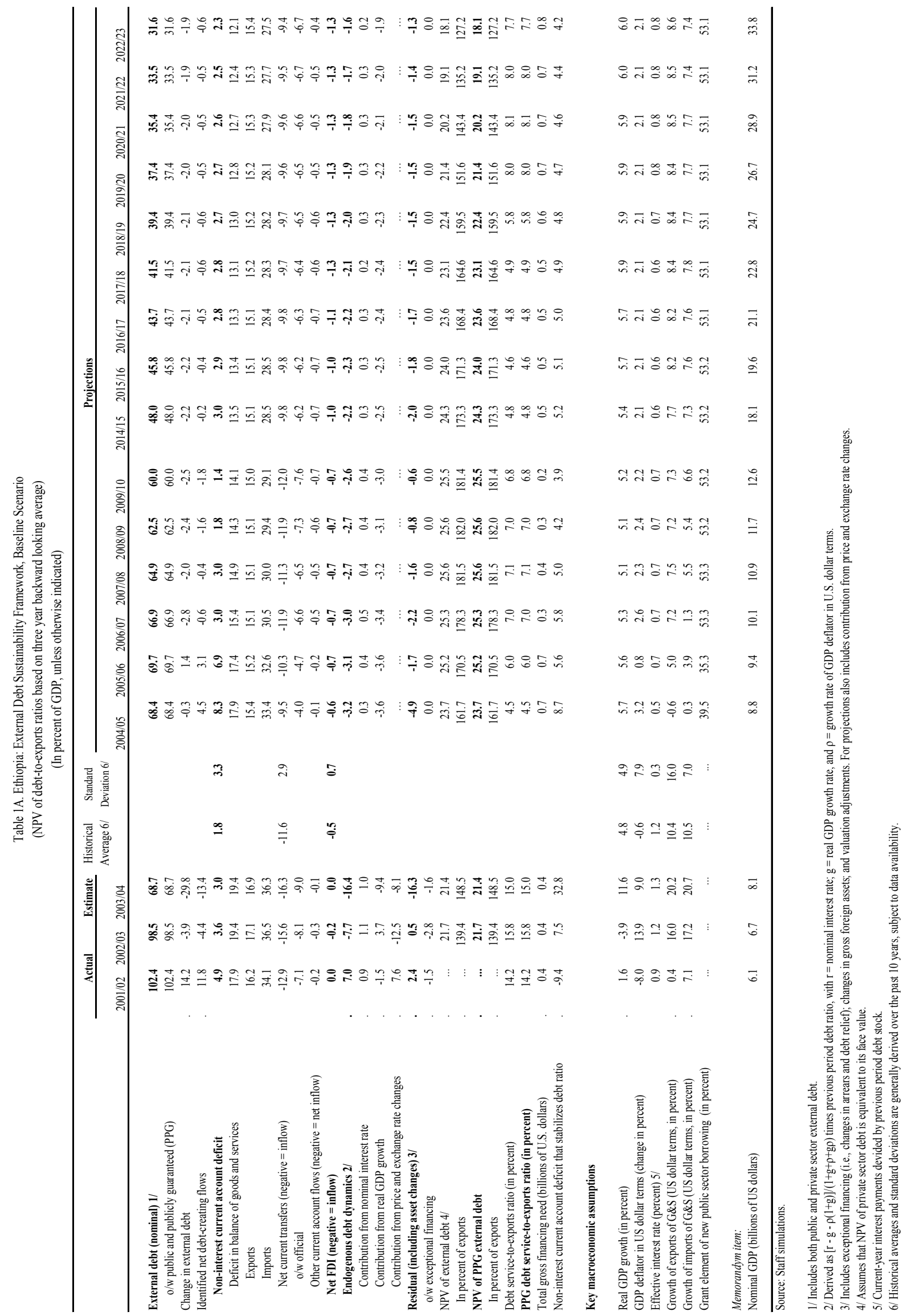


Table 1B. Ethiopia: Sensitivity Analyses for Key Indicators of Public and Publicly Guaranteed External Debt (NPV of debt-to-exports ratios based on three year backward looking average)

$$
\text { (In percent) }
$$

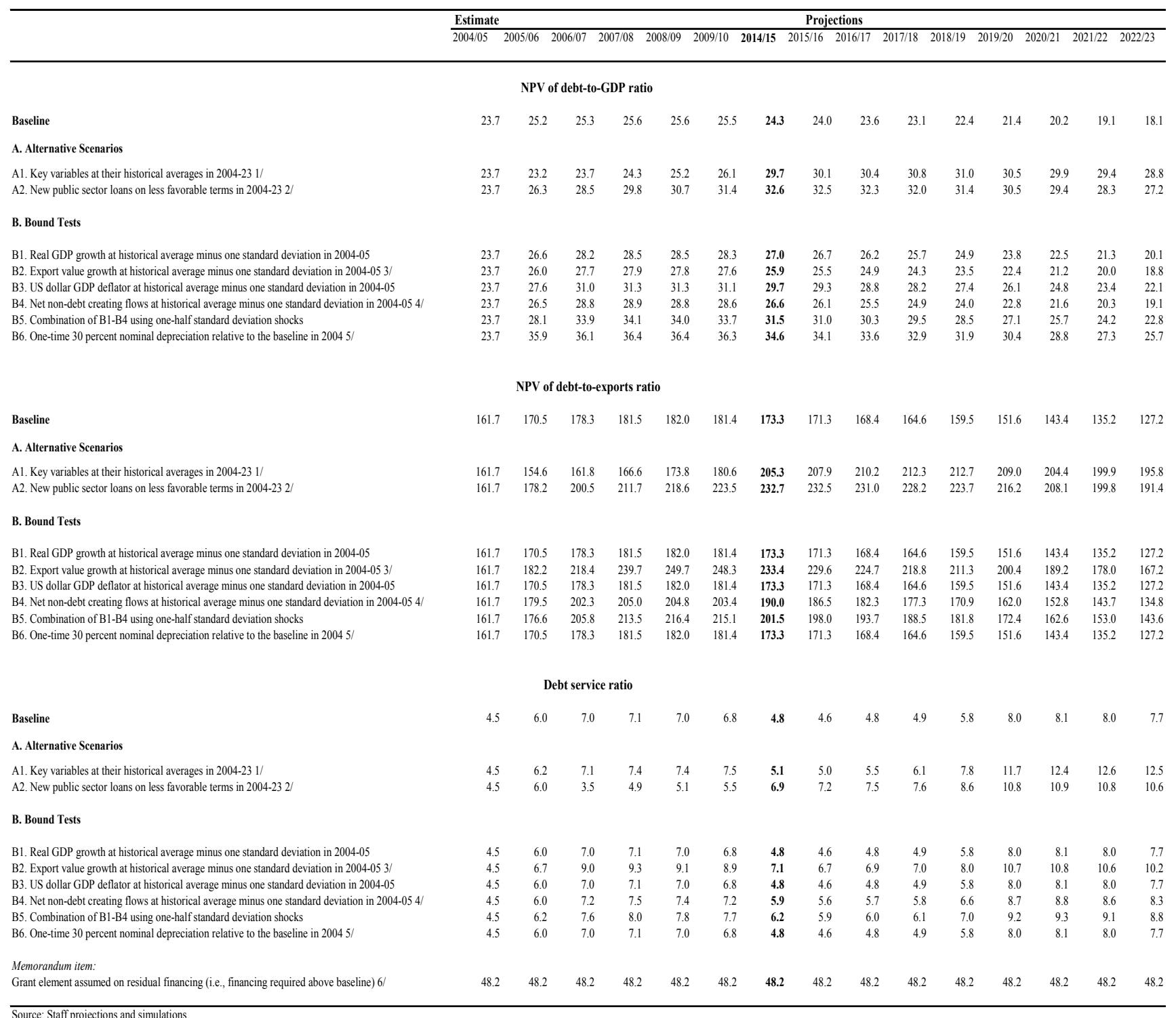

projections and simulations.

1/ Variables include real GDP growth, growth of GDP deflator (in U.S. dollar terms), non-interest current account in percent of GDP, and non-debt creating flows.

2/ Assumes that the interest rate on new borrowing is by 2 percentage points higher than in the baseline., while grace and maturity periods are the same as in the baseline.

3/ Exports values are assumed to remain permanently at the lower level, but the current account as a share of GDP is assumed to return to its baseline level after the shock (implicitly assuming

an offsetting adjustment in import levels).

4/ Includes official and private transfers and FDI.

5/ Depreciation is defined as percentage decline in dollar/local currency rate, such that it never exceeds 100 percent.

6/ Applies to all stress scenarios except for A2 (less favorable financing) in which the terms on all new financing are as specified in footnote 2. 
Figure 1. Ethiopia: Indicators of Public and Publicly Guaranteed External Debt Under Alternative Scenarios, (in percent)

(NPV of debt-to-exports ratios based on three year backward looking average)
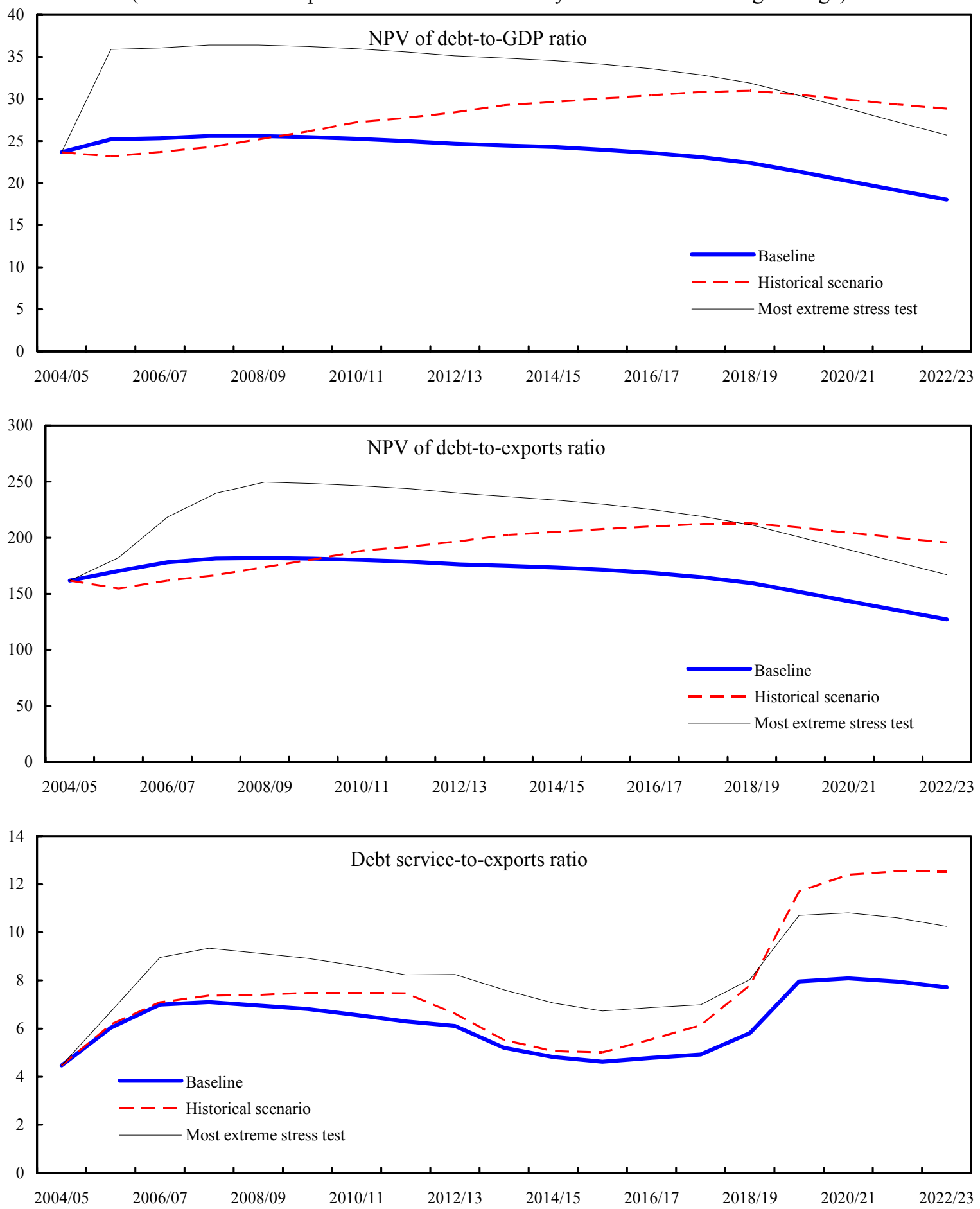

Source: Staff projections and simulations. 